\title{
PECUULIARIIIIES OF MENTAL EFFICIENCY AND PRDGRESS OF HIGHER GRADES STUDENTS BEGAN STUDYING AT THE AGE OF SIX AND SEVEN
}

Miziuk M.I., Suslyk Z.B., Yeremchuk YA.O.

\section{ОСОБЛИВОСТІ РОзУМОВОї ПРАЦЕЗДАТНОСТІ ТА УСППШНОСТІ УЧНІВ СТАРШИХ КЛАСІВ, ЯКІ РОзПОЧАЛИ НАВЧАННЯ 3 ШЕСТИ- \\ ТА СЕМИРІЧНОГО ВІКУ}

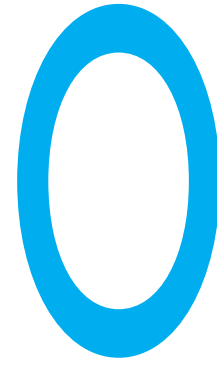

МІЗюК М.І., СУслИК З.Б., ЄРЕМЧУК Я.О.

Івано-Франківський національний медичний університет, м. Івано-Франківськ, Україна

УДК 613.955+613.8

Ключові слова: школярі, розумова працездатність, успішність. дним з найбільш інформативних критеріїв адаптації дитячого організму до навчального навантаження $€$ показники динаміки розумової працездатності, яка інтегрує основні властивості психіки (сприйняття, увага, пам'ять тощо) і $є$ однією з характеристик психічного здоров'я людини. 3 іншого боку, вона характеризує опірність організму учнів до стомлення [1]. При цьому розумова працездатність залежить від віку, річної і тижневої динаміки. Так, в учнів з 9 по 11 класи відбувається поступове зростання показників погодженості і продуктивності розумової працездатності 3 $(86,7 \pm 1,3)$ ум.од. до $(128,3 \pm 1,3)$ ум.од., що свідчить про адаптивну перебудову ЦНС до навчального навантаження [2].

На основі проведених досліджень виявлено, що перевищення тижневого гранично допустимого навчального навантаження на учнів старших класів становить 5 годин.
Виявлено збільшення кількості навчальних дисциплін у відповідних класах у середньому на $30 \%$; посилення навантаження на учнів молодшого шкільного віку (у 1970 році діти 7-річного віку вивчали 6 навчальних предметів, у 2013 році - 10), відсутність у старшій школі (10-11 класи) трудового виховання та велика кількість "статичних» предметів (у 10-11-х класах по 18-20 предметів), що впливає на якість засвоєння матеріалу і може бути фактором ризику появи хронічної втоми [3].

Основною причиною підвищення нервово-емоційного напруження $€$ високе навантаження на аферентні, центральні й еферентні ланки функціональних систем, що здійснюють трудову діяльність. За визначеного ступеня підвищення нервовоемоційного напруження виникає стан, коли порушується адекватна регуляція функцій і погіршуються результати діяльності.

\section{ОСОБЕННОСТИ УМСТВЕННОЙ}

РАБОТОСПОСОБНОСТИ И УСПЕВАЕМОСТИ УЧЕНИКОВ СТАРШИХ КЛАССОВ, НАЧАВШИХ ОБУЧЕНИЕ С ШЕСТИ- И СЕМИЛЕТНЕГО ВОЗРАСТА

Мизюк М.И., Суслик З.Б., Еремчук Я.А. Ивано-Франковский национальный медицинский университет, г. Ивано-Франковск, Украина Одними из наиболее информативных критериев адаптации детского организма к учебной нагрузке есть показатели динамики умственной работоспособности.

Цель работы. Установление особенностей умственной работоспособности и успеваемости старшеклассников общеобразовательных учебных заведений в сравнительном аспекте между учениками, начавшими обучение с 6 и 7 лет. Материалы и методы. Исследования проведены среди 937 учеников, начавших обучение с 6 лет, и 263 учеников, начавших обучение с 7 лет, в зависимости от пола (девочки, мальчики), класса (9-й, 10-й, 11-й), места жительства (город, село) и зоны Прикарпатья (горная, предгорная, равнинная, г. Ивано-Франковск). Оценка умственной работоспособности старшеклассников проводилась по результатам корректурной пробы до и после уроков по таблицам Анфимова.

Результаты. У учеников, начавших обучение с 6 лет, наблюдался более высокий уровень $(p<0,05)$ умственной работоспособности, а именно: по показателям количества просмотренных знаков, количества правильных действий, количества ошибок, коэффициента работоспособности в 11-м классе; показателям количества просмотренных знаков в горной зоне, в г. ИваноФранковске; по показателям количества пропущенных знаков в равнинной зоне до уроков и по показателям количества просмотренных знаков и количества правильных действий после уроков в г. Ивано-Франковске. Существенных отличий в динамике показателей в течение учебного дня между учениками по полу, месту жительства и зонами Прикарпатья нет.

Успеваемость детей по украинскому языку, алгебре, геометрии и по среднему баллу была существенно выше среди учеников, начавших обучение с 6 лет, а именно: у девочек (украинский язык, алгебра), у мальчиков (украинский язык, алгебра, геометрия и средний балл), в 9-м классе (украинский язык, алгебра, геометрия), в 10-м классе (украинский язык, алгебра, геометрия), у городских учеников (украинский язык, алгебра, геометрия и средний балл), у сельских учеников (алгебра, геометрия), у учеников г. Ивано-Франковска (украинский язык, алгебра, геометрия и средний балл).

Ключевые слова: школьники, умственная работоспособность, успеваемость.

๔ КМізюк М.І., Суслик З.Б., Єремчук Я.О. СТАТТЯ, 2018. 
Цей стан одержав назву "напруженості" [4].

Встановлено суттєвий вплив профілю навчання на динаміку розумової працездатності старшокласників, що навчаються у сільській місцевості, певні критичні періоди для розумової працездатності: початок року для фізико-математичного профілю навчання, середина - для філологічного, кінець навчального року - для природничого [5].

Високий рівень розумової працездатності $€$ показником сприятливого функціонального стану організму учнів. Між працездатністю й успішністю $€$ тісний зв'язок. Встановлено, що в усіх учнів з високим рівнем розумової працездатності відзначаються високі показники успішності [6].

Серед семирічних дітей частка вихованців з вираженим та сильним стомленням наприкінці навчального тижня $є$ значимо нижчою, ніж серед п'яти- та шестирічних $\left(\chi^{2}=13,8, p<0,05\right)$. За показниками функціонального стану ЦНС оптимальним віком для початку систематичного навчання у школі є 7 років [7].

Проте у науковій літературі немає повідомлень про те, чи є відмінності у психофізіологічному стані старшокласників, які розпочинали навчання у школі у різному віці: шестирічному та семирічному.

Мета дослідження. Встановлення особливостей розумової працездатності та успішності старшокласників загальноосвітніх навчальних закладів у порівняльному аспекті між учнями, які розпочали навчання 3 шести (НШР) та семи років (НСР).

Матеріали і методи. Дослідження проведено серед 937 учнів НШР та 263 учнів НСР залежно від статі (дівчата, хлопці), класу (9-й, 10-й, 11-й), місця проживання (місто, село) та зони Прикарпаття (гірська, передгірська, рівнинна, м. ІваноФранківськ).

Оцінка розумової працездатності старшокласників проводилася за результатами коректурної проби (КП) до і після уроків за таблицями Анфімова у модифікації С.М. Громбаха зі співавт. [8] з визначенням таких показників, як кількість переглянутих знаків, кількість правильних дій, кількість пропущених знаків, кількість помилок, коефіцієнт працездатності та коефіцієнт точності. Аналіз успішності шко-

Таблиця 1

Динаміка показників КП у старшокласників протягом навчального дня за класами

\begin{tabular}{|c|c|c|c|c|c|}
\hline \multirow{3}{*}{ Показник } & \multirow{3}{*}{ Клас } & \multicolumn{4}{|c|}{ Вік початку навчання } \\
\hline & & \multicolumn{2}{|l|}{6 років } & \multicolumn{2}{|l|}{7 років } \\
\hline & & $\mathrm{M} \pm \mathrm{m}$ & $\mathrm{n}$ & $\mathrm{M} \pm \mathrm{m}$ & $\mathrm{n}$ \\
\hline \multirow{3}{*}{$\begin{array}{l}\text { Кількість } \\
\text { переглянутих } \\
\text { знаків, шт. }\end{array}$} & 9 & $-54,15 \pm 6,69$ & 614 & $-53,69 \pm 13,28$ & 155 \\
\hline & 10 & $-29,04 \pm 9,68$ & 183 & $-46,46 \pm 16,77$ & 56 \\
\hline & 11 & $-14,76 \pm 15,46$ & 140 & $23,17 \pm 20,59$ & 52 \\
\hline \multirow{3}{*}{$\begin{array}{l}\text { Кількість } \\
\text { правильних дій, } \\
\text { шт. }\end{array}$} & 9 & $-12,70 \pm 1,90$ & 614 & $-15,20 \pm 3,83$ & 155 \\
\hline & 10 & $-10,57 \pm 2,36$ & 183 & $-12,82 \pm 3,73$ & 56 \\
\hline & 11 & $-1,61 \pm 3,09$ & 140 & $8,19 \pm 4,49$ & 52 \\
\hline \multirow{3}{*}{$\begin{array}{l}\text { Кількість } \\
\text { пропущених } \\
\text { знаків, шт. }\end{array}$} & 9 & $-0,56 \pm 0,50$ & 614 & $-0,15 \pm 0,67$ & 155 \\
\hline & 10 & $2,70 \pm 1,11$ & 183 & $2,91 \pm 1,20$ & 56 \\
\hline & 11 & $0,23 \pm 0,58$ & 140 & $0,67 \pm 1,43$ & 52 \\
\hline \multirow{3}{*}{$\begin{array}{l}\text { Кількість } \\
\text { помилок, } \\
\text { шт. }\end{array}$} & 9 & $0,40 \pm 0,35$ & 614 & $0,03 \pm 0,41$ & 155 \\
\hline & 10 & $0,34 \pm 0,29$ & 183 & $0,50 \pm 0,41$ & 56 \\
\hline & 11 & $-0,31 \pm 0,29$ & 140 & $0,75 \pm 0,35^{\star}$ & 52 \\
\hline \multirow{3}{*}{$\begin{array}{l}\text { Коефіцієнт } \\
\text { працездатності, } \\
\text { од. }\end{array}$} & 9 & $-51,44 \pm 7,91$ & 613 & $-51,92 \pm 14,19$ & 155 \\
\hline & 10 & $-56,76 \pm 10,09$ & 183 & $-71,34 \pm 14,80$ & 56 \\
\hline & 11 & $-15,26 \pm 14,58$ & 140 & $15,24 \pm 17,36$ & 52 \\
\hline \multirow{3}{*}{$\begin{array}{l}\text { Коефіцієнт } \\
\text { точності, од. }\end{array}$} & 9 & $-0,01 \pm 0,01$ & 613 & $0,00 \pm 0,01$ & 155 \\
\hline & 10 & $-0,03 \pm 0,01$ & 183 & $-0,03 \pm 0,01$ & 56 \\
\hline & 11 & $0,00 \pm 0,01$ & 140 & $0,00 \pm 0,01$ & 52 \\
\hline
\end{tabular}

Примітка до таблиць 1 і 2: * - достовірність $p<0,05$. лярів здійснювався на основі викопіювання оцінок з української мови, алгебри, геометрії за навчальний рік та за середнім балом.

Результати досліджень та їх обговорення. Динаміка змін показників КП протягом навчального дня за статтю школярів характеризується зменшенням кількості переглянутих знаків, кількості правильних дій, коефіцієнта працездатності та коефіцієнта точності, а також збільшенням кількості помилок як у дівчат, так і у хлопців, проте суттєвих відмінностей між учнями НШР та НСР не виявлеHO $(p>0,05)$

До уроків показники КП серед учнів 9-го, 10-го та 11-го класів не відрізнялися. Після уроків спостерігалося збільшення кількості переглянутих знаків в учнів НШР $(792,78 \pm 18,19)$ шт. порівняно 3 учнями НСР $(726,92 \pm$ $25,36)$ шт. $(p<0,05)$ в 11-му класі, кількості правильних дій - відповідно $(190,47 \pm 4,24)$ шт. та $(172,98 \pm 5,34)$ шт. $(p<0,05)$ в 11му класі, кількості пропущених знаків - $(7,59 \pm 0,63)$ шт. та $(5,04 \pm 0,66)$ шт. $(p<0,05)$ у 10 -мy класі, кількості помилок $(2,99 \pm 0,21)$ шт. та $(2,05 \pm 0,28)$ шт. $(\mathrm{p}<0,05)$ у 10 -му класі, коефіцієнта працездатності - $(730,35 \pm$ $17,04)$ од. та $(664,94 \pm 22,20)$ од. $(p<0,05)$ в 11-му класі, зменшення коефіцієнта точності $(0,90 \pm 0,01)$ од. та $(0,94 \pm 0,01)$ од. $(p<0,05)$ у 10 -му класі.

За динамікою змін показників КП протягом навчального дня (табл. 1) суттєві відмінності між учнями НШР та НСР виявлено тільки за кількістю помилок в 11 му класі - відповідно $(-0,31 \pm$ $0,29)$ шт. та $(0,75 \pm 0,35)$ шт. $(p<0,05)$. Збільшення кількості помилок відзначається в учнів HCP.

Суттєвих відмінностей між учнями НШР та НСР за показниками КП між міськими та сільськими школярами немає.

За результатами КП за зонами Прикарпаття встановлено, що до уроків суттеві відмінності між учнями НШР та НСР спостерігаються за показниками кількості переглянутих знаків - відповідно $(723,21 \pm 11,65)$ шт. та $(651,45 \pm$ $27,73)$ шт. $(p<0,05)$ у гірській зоні, $(643,40 \pm 10,77)$ шт. та $(706,31 \pm$ $23,87)$ шт. $(p<0,05)$ - у рівнинній зоні, $(686,74 \pm 12,97)$ шт. та $(642,03 \pm 18,55)$ шт. $(p<0,05)-$ в м. Івано-Франківську, а за показниками кількості пропущених знаків - відповідно $(8,54 \pm 0,72)$ шт. та $(5,93 \pm 1,01)$ шт. $(p<0,05)$ у 
PECULIARITIES OF MENTAL EFFICIENCY AND PROGRESS OF HIGHER GRADES STUDENTS BEGAN STUDYING AT THE AGE OF SIX AND SEVEN Miziuk M. I. , Suslyk Z.B., Yeremchuk YA.O. Ivano-Frankivsk National Medical University, Ukraine

Parameters of mental efficiency dynamics are the most informative criteria of the adaptation of child's organism to the educational load.

Objective. We established the peculiarities of mental efficiency and progress of higher grades students at secondary schools in comparison aspect among the students began studying at the age of six and seven. Materials and methods. The research was carried out among 937 students, started studying at the age of six and 263 students started studying at the age of seven, depending on gender (girls, boys), grade(9-th, 10-th, 11-th), place of residence (city, village) and the Prykarpattia's zone (mountain, foothill, plain, Ivano-Frankivsk city). Assessment of mental efficiency in the senior students was carried out by the results of corrective test according to Anfimov's tables before and after the lessons.

Results. A higher level $(p<0,05)$ of mental efficiency was observed in the students started studying at the age of six, namely by the parameters of the number of revised symbols, the number of correct actions, the number of errors, the coefficient of the efficiency in the 11-th grade; number of revised symbols in the mountain zone, in Ivano-Frankivsk city; according to the number of missed symbols in the plain zone before the lessons and to the number of revised symbols and the number of correct actions after the lessons in IvanoFrankivsk city.

There are no significant differences in the dynamics of the parameters during the school day in the students by gender, place of residence, and zones of the Carpathian region.

The progress of the students in Ukrainian, algebra, geometry and the average score are significantly higher among the children began studying at the age of six, namely in Ukrainian, algebra - in girls, in Ukrainian, algebra, geometry - in boys; in Ukrainian, algebra, geometry in the 9-th grade; in Ukrainian, algebra, geometry in the 10-th grade; in Ukrainian, algebra, geometry and average score - among the urban students; in algebra, geometry - among the rural students; in Ukrainian, algebra, geometry and average score-among the students of Ivano-Frankivsk city.

Keywords: students, mental efficiency, progress. гірській зоні, $(6,73 \pm 0,47)$ шт. та $(10,33 \pm 1,50)$ шт. $(p<0,05)$ - у рівнинній зоні.

Після уроків суттєві відмінності між учнями НШР та НСР спостерігаються тільки в м. ІваноФранківську за показниками кількості переглянутих знаків відповідно $(762,88 \pm 11,79)$ шт. та $(711,42 \pm 17,64)$ шт. $(p<0,05)$, за показниками кількості правильних дій - $(182,18 \pm 2,80)$ шт. та $(170,91 \pm 4,46)$ шт. $(p<0,05)$, за показниками кількості пропущених знаків - $(7,28 \pm 0,54)$ шт. та $(4,90 \pm 0,54)$ шт. $(p<0,05)$.

За динамікою змін показників КП протягом навчального дня за зонами Прикарпаття суттєвих відмінностей між учнями НШР та НСР не виявлено.

Стан успішності старшокласників аналізували за основними предметами: українська мова, алгебра, геометрія та за середнім балом між учнями НШР та учнями НСР.

Успішність дітей за статтю представлено у таблиці 2. Серед дівчат суттєві відмінності між учнями НШР та НСР встановлено $з$ української мови відповідно $(7,96 \pm 0,13)$ балів та $(7,28 \pm 0,25)$ балів $(p<0,05) ; 3$ алгебри - $(7,24 \pm 0,14)$ балів та $(6,47 \pm 0,35)$ балів $(p<0,05)$; серед хлопців - 3 української мови - відповідно $(8,36 \pm 0,14)$ балів та $(7,67 \pm 0,20)$ балів $(p<0,05) ; 3$ алгебри - $(7,60 \pm$ $0,15)$ балів та $(6,26 \pm 0,30)$ балів $(p<0,05) ; 3$ геометрії - $(7,54 \pm$ $0,15)$ балів та $(6,33 \pm 0,30)$ балів $(\mathrm{p}<0,05)$; за середнім балом $(7,82 \pm 0,14)$ балів та $(7,00 \pm 0,28)$ балів $(p<0,05)$. Характерним $\epsilon$ те, що в усіх випадках успішність учнів НШР є вищою, ніж в учнів HCP.

Під час вивчення успішності школярів залежно від класу суттеві відмінності між учнями НШР та НСР встановлено у 9-му класі: $з$ української мови - відповідно $(8,07 \pm 0,13)$ балів та $(7,54 \pm 0,22)$ балів $(p<0,05) ; 3$ алгебри - $(7,22 \pm 0,14)$ балів та $(6,17 \pm 0,32)$ балів $(p<0,05) ; 3$ геометрії - $(7,13 \pm 0,14)$ балів та $(6,26 \pm 0,35)$ балів $(p<0,05) ;$ у $10-$ му класі: 3 української мови відповідно $(8,14 \pm 0,15)$ балів та $(7,27 \pm 0,29)$ балів $(p<0,05) ; 3$ алгебри - $(7,69 \pm 0,16)$ балів та $(6,52 \pm 0,41)$ балів $(p<0,05) ; 3$ геометрії - $(7,72 \pm 0,17)$ балів та $(6,65 \pm 0,39)$ балів $(p<0,05)$. Суттєвих відмінностей між учнями НШР та НСР в 11-му класі не виявлено. Загалом успішність

\section{Успішність старшокласників за статтю}

\begin{tabular}{|c|c|c|c|c|c|}
\hline \multirow{3}{*}{ Показник } & \multirow{3}{*}{ Стать } & \multicolumn{4}{|c|}{ Вік початку навчання } \\
\hline & & \multicolumn{2}{|c|}{6 років } & \multicolumn{2}{|c|}{7 років } \\
\hline & & $\mathrm{M} \pm \mathrm{m}$ & $\mathrm{n}$ & $\mathrm{M} \pm \mathrm{m}$ & $\mathrm{n}$ \\
\hline \multirow{2}{*}{$\begin{array}{l}\text { Українська } \\
\text { мова, бали }\end{array}$} & Дівчата & $7,96 \pm 0,13$ & 304 & $7,28 \pm 0,25^{\star}$ & 83 \\
\hline & Хлопці & $8,36 \pm 0,14$ & 228 & $7,67 \pm 0,20^{*}$ & 92 \\
\hline \multirow{2}{*}{ Алгебра, бали } & Дівчата & $7,24 \pm 0,14$ & 304 & $6,47 \pm 0,35^{\star}$ & 83 \\
\hline & Хлопці & $7,60 \pm 0,15$ & 228 & $6,26 \pm 0,30$ * & 92 \\
\hline \multirow{2}{*}{$\begin{array}{l}\text { Геометрія, } \\
\text { бали }\end{array}$} & Дівчата & $7,21 \pm 0,14$ & 305 & $6,58 \pm 0,35$ & 83 \\
\hline & Хлопці & $7,54 \pm 0,15$ & 230 & $6,33 \pm 0,30$ * & 92 \\
\hline \multirow{2}{*}{ Середній бал } & Дівчата & $7,47 \pm 0,13$ & 300 & $6,97 \pm 0,31$ & 73 \\
\hline & Хлопці & $7,82 \pm 0,14$ & 226 & $7,00 \pm 0,28 *$ & 77 \\
\hline
\end{tabular}

учнів НШР $є$ вищою, ніж в учнів HCP.

Вивчення успішності школярів залежно від місця проживання теж виявило суттєві відмінності між учнями НШР та НСР, зокрема серед міських школярів: 3 української мови - відповідно $(8,27 \pm 0,14)$ балів та $(7,49 \pm 0,20)$ балів $(p<0,05)$; 3 алгебри $(7,51 \pm 0,14)$ балів та $(6,34 \pm 0,29)$ балів $(p<0,05)$; 3 геометрії $(7,50 \pm 0,14)$ балів та $(6,56 \pm 0,28)$ балів $(p<0,05) ;$ за середнім балом - $(7,76 \pm 0,13)$ балів та $(6,95 \pm 0,24)$ балів $(p<0,05)$; серед сільських школярів: 3 алгебри - $(7,30 \pm 0,14)$ балів та $(6,39 \pm 0,39)$ балів $(p<0,05) ; 3$ геометрії - $(7,24 \pm 0,15)$ балів та $(6,23 \pm 0,39)$ балів $(p<0,05)$. При цьому успішність учнів НШР $€$ вищою, ніж в учнів НСР.

Під час вивчення успішності школярів залежно від зони

Таблиця 2 
Прикарпаття суттєві відмінності між учнями НШР та НСР встановлено тільки серед старшокласників м. Івано-Франківська: з української мови - відповідно $(8,45 \pm 0,21)$ балів та $(7,29 \pm 0,26)$ балів $(p<0,05) ; 3$ алгебри $(7,38 \pm 0,19)$ балів та $(6,19 \pm 0,34)$ балів $(p<0,05)$; 3 геометрії $(7,45 \pm 0,19)$ балів та $(6,41 \pm 0,31)$ балів $(p<0,05) ;$ за середнім балом - $(7,78 \pm 0,18)$ балів та $(6,59 \pm 0,30)$ балів $(p<0,05)$.

Суттєвих відмінностей між учнями НШР та НСР у гірській, передгірській та рівнинній зонах не виявлено. Успішність учнів НШР є вищою, ніж в учнів НСР.

\section{Висновки}

1. В учнів НШР спостерігається вищий рівень $(p<0,05)$ розумової працездатності порівняно з учнями НСР, зокрема за показниками кількості переглянутих знаків, кількості правильних дій, кількості помилок, коефіцієнта працездатності в 11-му класі; кількості переглянутих знаків у гірській зоні, в м. ІваноФранківську; за показниками кількості пропущених знаків у рівнинній зоні до уроків та за показниками кількості переглянутих знаків та кількості правильних дій після уроків в м. Івано-Франківську.

2. За динамікою змін показників КП протягом навчального дня суттєві відмінності між учнями НШР та НСР виявлено тільки за кількістю помилок в 11-му класі - зменшення в учнів НШР $(-0,31 \pm 0,29)$ шт. та збільшення в учнів НСР - $(0,75 \pm 0,35)$ шт. Суттєвих відмінностей у динаміці показників протягом навчального дня між учнями НШР та НСР за статтю, місцем проживання та зонами Прикарпаття немає.

3. Успішність дітей з української мови, алгебри, геометрії та за середнім балом суттєво вища серед дітей НШР у дівчат (українська мова, алгебра) та хлопців (українська мова, алгебра, геометрія та за середнім балом), у 9-му класі (українська мова, алгебра, геометрія), у 10му класі (українська мова, алгебра, геометрія), у міських школярів (українська мова, алгебра, геометрія та за середнім балом), у сільських школярів (алгебра, геометрія), у школярів м. Івано-Франківська (українська мова, алгебра, геометрія та за середнім балом). Суттєвих відмінностей за успішністю між учнями НШР та НСР у гірській, передгірській та рівнинній зонах немає.
ЛІТЕРАТУРА :

1. Кузнецова Л.М., Кузнецов В.Д., Тимошенко К.Т. Показатели психического здоровья современных старшеклассников и студентов вуза. Гигиена и санитария. 2008. № $3.59 \mathrm{c}$.

2. Щудро С.А. Критеріальне значення соціально-гігієнічних чинників та умов навчання у формуванні здоров'я підлітків загальноосвітніх закладів у сучасних умовах : автореф. дис. ... докт. мед. наук :

14.02.01 «Гігієна та професійна патологія». К., 2011. 37 с.

3. Гозак С.В., Шумак О.В. Шкільне середовище як фактор ризику для здоров'я учнів. Гігієна населених місць : зб. наук. пр. К., 2014. Вип. 63. C. 61-64.

4. Бардов В.Г., Сергета І.В. Перспективи використання рівня фізичної працездатності як кількісного показника здоров'я дітей та підлітків. Довкілля та здоров'я. 1999. № 1. С. 14-17.

5. Даниленко Г.М.,

Сотникова-Меклешкіна Ж.В. Розумова працездатність сільських старшокласників при профільному навчанні. Гігієна населених місць : зб. наук. пр. К., 2010. Вип. 56. С. 298-304.

6. Поташнюк Р.3.

Закономірності змін стану здоров'я, працездатності та успішності навчання школярів.

Науковий вісник ВДУ. Сер. Здоров'я, фізична культура і спорт. Луцьк, 1997. № 6.

C. 47-49.

7. Гозак С.В., Філоненко О.О., Парац А.М. Вивчення розумової працездатності дітей старшого дошкільного віку. Актуальні питання гігієни та екологічної безпеки України : зб. тез доп. наук. -практ. конф.

(Х Марзєєвські читання). Київ, 2014. С. 196-198.

8. Методические рекомендации по комплексной оценке состояния здоровья детей и подростков при массовых врачебных осмотрах / под ред. С.М. Громбаха. М. : Медицина, 1982. 17 C

\section{REFERENCES}

1. Kuznetsova L.M., Kuznetsov V.D. and Tymoshenko K.T. Gigiena i sanitaria. 2008 ; 3 : 59 (in Russian).

2. Shudro S. A. Kryterialne znachennia sotsialno-hihiienichnykh chynnykiv ta umov navchannia u formuvanni zdorovia pidlitkiv zahalnoosvitnikh zakladiv u suchasnykh umovakh : avtoref. dys. ... dokt. med. nauk [Criterial Significance of Social-andEconomical Factors and Conditions of Education in the Formation of the Adolescents' Health at Secondary Schools under Modern Conditions : Abstract of Doctor of Medicine Diss.]. Kyiv; 2011 : 37 p. (in Ukrainian).

3. Hozak S.V., and Shumak O.V. Shkilne seredovyshche yak factor ryzyku dlia zdorovia uchniv [School Medium as a Risk Factor for Pupils' Health]. In : Hihiiena naselenykh mists [Hygiene of Settlements]. Kyiv, 2014 ; 63 : 61-64 (in Ukrainian).

4. Bardov V.H. and Serheta I.V. Dovkillia ta zdorovia. 1999 ; 1 : 14-17 (in Ukrainian).

5. Danylenko G.M. and Sotnikova-Mekleshkina Zh.V. Rozumova pratsezdatnist silskych starshoklasnykiv pry profilnomu navchanni [Mental Efficiency of Rural Senior Pupils at Specialized Education]. In : Hihiiena naselenykh mists [Hygiene of Settlements]. Kyiv, 2010; 56: 298-304 (in Ukrainian).

6. Potashniuk R.Z.

Zakonomirnosti zmin stanu zdorovia, pratsezdatnosti ta uspishnosti navchannia shkoliariv [Regularities of Changes in the State of Health, Efficiency, and Educational Progress of the Pupils]. In : Naukovyi visnyk Volynskoho derzhavnoho universytetu. Zdorovia, fizychna kultura i sport [Scientific Bulletin of Volyn State University. Health, Physical Training, and Sport]. Lutsk, 1997; 6 : 47-49 (in Ukrainian).

7. Hozak S.V., Filonenko O.O. and Parats A.M. Vyvchennia rozumovoi pratsezdatnosti ditei starshogo doshkilnoho viku [Study of Mental Efficiency in the Senior Pre-School Age Children]. In : Aktualni pytannia higiieny ta ekolohichnoi bezpeky Ukrainy : mater. konf. [Actual Issues of Hygiene and Economical Safety of Ukraine: Mater. of Conf.]. Kyiv ; 2014 : 196-198 (in Ukrainian).

8. Grombakh S.M. (ed.) Metodicheskiye rekomendatsii po kompleksnoy otsenke sostoyaniya zdorovya detei i podrostkov pri massovykh vrachebnykh osmotrakh [Methodical Recommendations on the Complex Assessment of the State of Health of Children and Adolescents at Mass Medical Examinations]. Moscow : Meditsina ; 1982 : $17 \mathrm{p}$. (in Russian).

Надійшла до редакції 24.10.2017 